\title{
Vztah ředitele a učitelského sboru ve vybraných evropských státech $v$ kontextu autonomie škol1
}

\author{
Zuzana Svobodová, Václav Trojan \\ Univerzita Karlova, Pedagogická fakulta
}

\begin{abstract}
Abstrakt: Tato studie se zaměřuje na analýzu rozsahu autonomie škol a jejich ředitelů v práci s lidskými zdroji a vliv míry autonomie na konkrétní vztah a pozici ředitele školy vǔči učitelskému sboru. Rozebírá možnosti sestavování učitelského sboru, vybírání a propouštění jednotlivých učitelů, jejich rozvoj a nástroje evaluace, odměňování a řízení rozvoje. Pro tuto studii jsou zvoleny dva školské systémy - německý a rakouský. Tyto dva systémy je možné považovat za centrálně řízené, přičemž se $v$ posledních letech diskutuje a plánuje postupné posilování autonomie tamních škol. Přes dlouhodobé snahy o posílení autonomie se nedávné reformy zaměřují spíše na standardizaci vzdělávacích výstupů, a tím zvýšení kvality vzdělávání. Prezentovaná zjištění jsou v tomto textu komparována se situací v České republice, což přispívá k hlubšímu pochopení role českého ředitele a jeho vztahu s pedagogickým sborem a zároveň jeho roli zasazuje do mezinárodního kontextu. Z metodologického hlediska se jedná o komparativní studii doplněnou př́klady autentických výroků respondentů působících na různých pozicích v rámci srovnávaných vzdělávacích systémů.
\end{abstract}

Klíčová slova: autonomie školy, školský systém, ředitel školy, pedagogické vedení

\section{The Relationship Between the Headteacher and the Teaching Staff in Selected European Countries in the Context of School Autonomy}

Abstract: This study is focused on the analysis of the scope of autonomy of schools and their headteachers in the work with human resources and its influence on a specific relation and the position of the headteacher of the school towards the other teachers. It analyses the possibilities of creating a teaching staff, selecting and dismissing individual teachers, their development and tool of evaluation, their rewarding and leading of the development. Two school systems are selected for this study - German and Austrian. These two systems may be considered as centrally controlled and in the latest years, the progressive strengthening of autonomy of the schools has been discussed and planned. In spite of the long attempts to strengthen the autonomy, the reforms in the last years have been focused rather on the standardization of the performance of the teaching increasing thereby the quality of education. The presented findings within this text are compared to the situation in the Czech Republic, which contributes to deep understanding of the role of the Czech headteacher and his/her relation to the teaching staff involving his/her role in the international context. This text is completed by concrete examples of authentic practice.

Keywords: autonomy of schools, the educational system, headteacher of school, instructional leadership

1 Text vznikl za podpory projektu PROGRES Q17 „Příprava učitele a učitelská profese v kontextu vědy a výzkumu“.

(c) 2018 The Authors. This is an open-access article distributed under the terms of the Creative Commons Attribution License (http://creativecommons.org/licenses/by/4.0), which permits unrestricted use, distribution, and reproduction in any medium, provided the original author and source are credited. 
48 Ve studii hledáme odpovědi na otázky: Co přináší autonomie školy v oblasti lidských zdrojů učitelským sborům? Jaké požadavky jsou kladeny na ředitele ve školských systémech s rozdílnou mírou autonomie? Při hledání odpovědí na tyto základní otázky se opíráme o informace o pedagogických sborech, sledujeme proces jejich vytváření a práci s nimi v centrálně ř́zených školských systémech, konkrétně v Německu a Rakousku, které průběžně komparujeme se situací v České republice. $\mathrm{S}$ ohledem na rozdílný rozsah školské legislativy a školské struktury se zaměřujeme na učitelské sbory ve školách poskytujících primární a nižší sekundární vzdělávání, tj. v době, která ve zmíněných státech (včetně České republiky) zahrnuje období povinné školní docházky. ${ }^{2}$ Článek popisuje především oblast sestavování učitelských sborů a problematickou sféru ukončování spolupráce, tj. propouštění učitelů, přičemž v souvislosti $s$ tím reflektuje i rozvoj a hodnocení učitelů $v$ rámci kompetencí ředitelů a dalších aktérů vzdělávání.

Školské systémy Německa a Rakouska byly vybrány záměrně, a to z několika důvodů - $v$ současné době jsou sice centrálně řízené, ale jsou $v$ nich patrné tendence $\mathrm{k}$ posilování školské autonomie a prochází v tuto dobu výraznými systémovými změnami, které budou postupně posilovat pravomoci škol a jejich ředitelů. ${ }^{3}$ Tyto státy mají také společný historický základ $v$ centrálně rízených školských systémech tehdejšího Rakouska-Uherska a Německa, ze kterých vycházely i jejich moderní školské systémy, přestože se pak historickým vývojem a událostmi 20 . století vydaly různými směry. Považujeme tedy za př́nosné si uvědomit historickou souvislost a cestu, kterou se školské systémy ubíraly a jak ve výsledku působí na učitelské sbory $\checkmark$ popisovaných státech.

Získané poznatky zasazujeme v závěrečné diskusi také do aktuální situace týkající se v současné době aktuálních témat, jako jsou školská autonomie a její posilování a spravedlivost ve vzdělávání. Tato témata úzce souvisejí s tím, jakým zpưsobem fungují učitelské sbory a jaké pravomoci školy a jejich ředitelé mají (srov. např. Greger, 2006; Dvořák, Urbánek, \& Starý, 2014; Trojan, 2017).

\section{1 Širší kontext problematiky}

Dobře sestavený, fungující a funkční učitelský kolektiv je pro kvalitu každé školy jistě jedním z nezbytných předpokladů (např. Barber \& Mourshed, 2007; Lukas, 2009; Janík et al., 2011; Tomková, 2012). Bez ohledu na vybavení škol, lokalitu, složení žáků či dalších aspektů, které jsou ve školách hodnoceny a podle kterých se uvažuje o tom, zda jde o „dobrou školu“, jsou to právě učitelské sbory a samotní učitelé, kteří jsou pro kvalitu výchovně-vzdělávacího procesu klíčoví. Řada odborníků dovozuje na základě empirických zjištění, že ředitelé škol jsou kličovými ak-

2 V Německu např́klad nejsou mateřské školy zařazeny do sítě škol a pedagogičtí zaměstnanci nejsou učiteli, ale vychovateli, řídí se tedy odlišnou legislativou.

3 V Rakousku kupríkladu již schválený baličé pro školní autonomii (Schulautonomiepaket), viz dále $v$ textu. 
téry změny ve vzdělávacích systémech (Huber, 2009; Behbahani, 2011; Leithwood, Sun, \& Pollock, 2017). Přitom tlak na změny ve vzdělávání a potažmo ve fungování škol je kvưli rostoucímu tempu sociokulturních, technických a dalších změn stále větší (Kuuskorpi \& Cabellos González, 2011; Moree, 2013). Jak dále uvádí také Lukas (2009), je to ředitel, kdo ovlivňuje vývoj učitele, a potažmo tedy i kvalitu výuky, která je bez dobrých učitelů nemyslitelná. Ředitel školy působí na učitele po celou dobu jejich kariéry, a jeho vliv je dle Lukase (tamtéž) dokonce jedním $z$ hlavních důvodů pro opouštění této profesní dráhy $v$ prvních pěti letech. Růst role managementu školy je doložen řadou empirických výzkumů a studií (Leithwood, 2005; Mulford, 2008; Obdržálek \& Polák, 2008; Robinson, Hohepa, \& Lloyd, 2009; Abari-Ibolya \& Baráth, 2010), které dokládají, že způsob a úroveň vedení školy patří k zásadním činitelům ovlivňujícím učení žáků a tím i celkovou kvalitu a efektivitu školy. Zároveň je však zřejmé, že růst role managementu školy není vyvažován poklesem role učitele. Ten je i v nové situaci nezpochybnitelným činitelem rozvoje kvalitní školy, je vnímán jako klíčový aktér proměny školy např́č zeměmi OECD. Role učitele a jeho vliv na edukační procesy nejsou zpochybňovány. Budeme-li tedy hovořit o zvyšování vlivu managementu školy na kvalitu vzdělávání, máme na mysli vždy pưsobení ředitelů $v$ interakci s působením učitelských sborů. Četné výzkumy opakovaně ukazují, že procesy vedení jsou významnou determinantou kvality a efektivity školní práce a že jde o zcela zásadní jev, jemuž je třeba věnovat pozornost (Lazarová, Pol, \& Sedláček, 2015). Důležité pro kvalitu vzdělávání přitom nejsou pouze činnosti a procesy, které vykonávají aktéři vzdělávání na pozicích učitele a ředitele sami o sobě, ale rovněž kvalita interakcí a vztahů, které mezi nimi panují.

České školy se v mezinárodním srovnání řadí mezi nejvíce autonomní (např. Eurydice, 2007; School autonomy..., 2011), a to jak z hlediska kurikula, tak i zdrojů (též lidských). V České republice je s ohledem na autonomní postavení škol sestavování učitelského sboru plně v kompetenci ředitele školy, který své budoucí kolegy vybírá a spolu s nimi vytváří specifický profil své školy. Umožňuje mu to tak např́klad orientovat svůj výběr podle jedinečného školního vzdělávacího programu a zaměření školy, přizpůsobit jej specifickým potřebám, které jeho škola má, i vizím, které chce ve své škole společně se svým týmem naplňovat. Je možné tedy říci, že český ředitel školy je plně odpovědný za to, jaký pedagogický sbor má (alespoň teoreticky - viz dále kap. 3) a jak rozvíjí jeho potenciál.

Mezi kompetence českého ředitele školy rovněž náleží řešení problematických pracovních situací a vyrovnávání se s př́padně nekvalitní pedagogickou prací. V jeho pravomoci je přijímat i propouštět učitele. $Z$ hlediska těchto pravomocí je pozice českého ředitele ojedinělá, v řadě evropských zemí má ředitel výrazně menší vliv na to, z jakých konkrétních učitelů bude pedagogický sbor složen, a problematika propouštění pedagogů je zpravidla zcela mimo jeho kompetence, $v$ některých zemích je dokonce $v$ podstatě nemožná, jak popisujeme dále $v$ textu.

V Německu má každá spolková země vlastní školskou legislativu, která specifikuje jednotlivé druhy a stupně škol, délku školní docházky, práva a povinnosti učitelů, 
50 ředitelů, rodičů a žáků. ${ }^{4}$ Společné pro všechny německé spolkové země je, že povolání učitele ve veřejných školách je služebním poměrem a jeho vykonávání je řízeno př́slušným školským úřadem dané spolkové země, at’ už na základě úřednického jmenování, nebo služebního smluvního vztahu.

V Rakousku dochází nyní ke zcela zásadní změně, kterou s sebou přináší tzv. balíček pro školní autonomii (Schulautonomiepaket), který dává školám a jejich ředitelům zcela nové pravomoci a umožňuje jim např́klad vybírat si učitele pro svou školu (Die Regierung präsentiert..., 2017). Do této doby měli tuto možnost pouze ředitelé soukromých škol, do státních škol byli učitelé přidělováni odpovědným školním inspektorem (Pflichtschulinspektor).

\subsection{Pozice učitelů a ředitelů škol}

Pro pochopení učitelských sborů je nutné osvětlit odlišnou pozici učitelů a ředitelů $\checkmark$ jednotlivých státech a rozdělení pravomocí související s rozsahem autonomie, kterou jednotlivé školy a ředitelé mají. Česká republika má $s$ ohledem na silnou míru autonomie ve všech oblastech zcela specifickou pozici mezi evropskými státy, obdobně rozsáhlé pravomoci svěřené školám jsou například již jen ve Spojeném království a Nizozemsku (School autonomy..., 2011). Z historického hlediska vychází české školství ze společného rakousko-uherského vzdělávacího modelu, o který se opíralo v podstatě až do poválečného období, tj. do roku 1948. Poté bohužel došlo ke změně orientace českého školství s ohledem na politické změny a začlenění tehdejšího Československa mezi země tzv. východního bloku, což mělo nejen pro další vývoj vzdělávání fatální dopad. Tehdejší československé školství bylo centrálně řízeno, ředitel vykonával správu školy a orientoval se především na administrativní a pedagogickou oblast, jeho rozhodovací pravomoci byly omezené jak $v$ oblasti zdrojů (finančních i lidských), tak i v kurikulární oblasti. Škola se dostávala pod silný politický tlak a rozhodovací možnosti ředitele byly politicky determinovány.

Až po roce 1989 došlo $v$ České republice $k$ postupné silné decentralizaci škol, která vyvrcholila v roce 2000 reformou státní správy, a dále v souvislosti s platností nového školského zákona od 1. ledna 2005 (zákon č. 561/2004 Sb., o předškolním, základním, středním, vyšším odborném a jiném vzdělávání) se přesunula rozhodovací pravomoc $z$ dřive centrálně řízeného školství na nejnižší možnou úroveň, tj. přímo na jednotlivé školy (MŠMT, 2009). Přičemž je to právě ředitel školy jako statutární zástupce, který má ve své kompetenci utváření její podoby, a to i z hlediska lidských zdrojů, jejich výběru a práce s nimi. S ohledem na tyto pravomoci je jeho pozice ojedinělá. $V$ souvislosti s novou školskou legislativou $v$ roce 2005 byla v každé škole povinně zř́zena školská rada. Vzhledem $\mathrm{k}$ nastavení jejích pravomocí zejména směrem ke školnímu kurikulu a hodnocení žákủ se k personální situaci může vyjádřit jen neprímo.

4 Pokud používáme $v$ textu označení Německo, jedná se o obecné označení s obecnou platností pro celé Německo, specifika jednotlivých spolkových států pak uvádíme konkrétně, tj. napríklad Sasko nebo Hamburk. 
V Německu a v Rakousku má ředitel v této oblasti výrazně menší pravomoci, je zodpovědný spolu se školskou a učitelskou konferencí za správu školy (Schulverwaltung) a „vykonává v běžných záležitostech služební dohled. Stará se o dodržování služebních povinností...“ (§ 89 odst. 2 hamburského školského zákona). Učitelé v obou těchto státech jsou státními zaměstnanci a mohou se stát i státními úředníky s doživotním jmenováním (Beamter). Jmenovací proces do funkce státního úředníka (Verbeamtung der Lehrkräfte) je ale odlišný $v$ jednotlivých spolkových zemích 5 a rovněž i v Rakousku, kde se od této možnosti pomalu upouští. Každoročně dochází k postupnému snižování počtu státních úředníků a posiluje se pozice jednotlivých spolkových zemí i spolupráce s učiteli na základě státního smluvního vztahu. O status státního úředníka učitelé zpravidla usilujíí, protože jim to přináší řadu výhod a hlavně doživotní jistotu zaměstnání. V Rakousku byla v září 2017 zveřejněna důležitá novela školského zákona (Schulunterrichtsgesetz), která nově ukládá řediteli povinnost koncepčně zajistit kvalitu školy $v$ souladu s národním rámcem a definuje nově jeho manažerskou úlohu a zodpovědnost vưči státu i povinnost vést jemu svěřené učitele tímto směrem. Učitelé jsou ale nadále státními zaměstnanci, ředitel nese odpovědnost za kvalitu jejich práce (Bildungsreformgesetz, 2017).

$\checkmark$ těchto státech jsou tedy učitelé na pozici státních zaměstnanců (ve služebním poměru či na základě smluvního vztahu), která je řízena a garantována státem. Němečtí ředitelé se zodpovídají příslušnému školskému úřadu (Schulbehörde) a rakouští svému školnímu inspektorovi (Pflichtschulinspektor). Ředitelé jsou sice přímými nadřizenými svých učitelů, nerozhodují ale přímo o jejich výběru, mohou je v omezeném a přesně stanoveném rozsahu hodnotit, ale nemohou je v žádném případě propouštět. Na německé a rakouské ředitele je tedy kladen svým zpưsobem značně komplikovaný požadavek, a to nutnost zajistit kvalitu pedagogického procesu bez možnosti výběru učitelů jako základních aktérů pedagogického procesu.

Za myšlenkou centrálního výběru učitelů a centrálního zajištění učitelských sborů stojí zodpovědnost státu za kvalitu vzdělávání. Stát zodpovídá za poskytování vzdělávání ve „svých“ školách, proto je také odpovědný za personální zajištění pedagogické práce. $Z$ tohoto důvodu je z hlediska centrálně řizených systémů legitimní ovlivňovat sestavování učitelských sborů, rozhodovat o jejich odměňování a i o setrvání v dané škole či přeložení na jinou školu (propouštění je v těchto prípadech spíše nemožné). Nutně tedy vyvstávají otázky, jak vlastně funguje personální a pedagogické rízení škol, jak může ředitel prosazovat nějakou pedagogickou vizi nebo směr ve své škole a jak vůbec může fungovat tým, který nevybírá sám ředitel se znalostí svých zaměstnanců a potřeb školy? Pro české ředitele je situace, kdy dostanou přidělené rưznorodé učitele, jejichž pedagogické působení nemohou vlastně ani hodnotit, pravděpodobně nepředstavitelná. „Je to zvláštní, vlastně se to vůbec neřeší, to je pravda, ale nějak to pak prostě funguje, “ uvedla oborová pedagogická koordinátorka.

5 Tuto možnost s určitými omezeními mají učitelé ve všech spolkových zemích kromě Berlína a Durynska (Sofatutor, 2016).

$6 \quad V$ rozhovoru uváděli oba ředitelé německých škol, že je mezi jejich učiteli velká snaha tento status získat. Podmínkou pro jeho udělení je zpravidla délka učitelské praxe. V některých spolkových státech je tento status udělován přednostně členům vedení a širšího vedení školy. 


\section{Metodologie}

\subsection{Cíl studie a výzkumná otázka}

Cílem studie je popsat, co přináší autonomie školy v oblasti lidských zdrojů učitelským sborům ve vybraných státech (tj. Německu a Rakousku), a zjištění porovnat se situací v České republice. Základní výzkumné otázky - Co přináší autonomie školy v oblasti lidských zdrojů učitelským sborům? Jaké požadavky jsou kladeny na ředitele ve školských systémech s rozdílnou mírou autonomie? - jsme rozpracovali do dílčích otázek a témat:

- Jakým způsobem jsou vytvářeny učitelské sbory ve vybraných státech a jakým zpưsobem mohou ředitelé škol tento proces ovlivňovat?

- Jaké možnosti v motivaci a odměňování učitelů mají ředitelé škol ve vybraných státech?

- Jak vnímají ředitelé své pravomoci vưči učitelskému sboru ve vybraných státech?

- Jaké možnosti mají ředitelé v situaci, kdy práce učitelů není z jejich hlediska kvalitní?

\subsection{Výzkumná metoda a vzorek}

Studii je možné metodologicky zařadit do oblasti srovnávací pedagogiky. Získané poznatky vycházejí především jednak z tzv. desk research, tj. z rešerše, studia a interpretace informací z relevantních legislativních dokumentů, odborných příspěvků a výzkumných zpráv (ojediněle čerpáme i z popularizujících tematických zpráv a v případě aktuálních otázek využíváme jako zdroj také informace zveřejňované na webových stránkách př́slušných školských ministerstev, úřadů a obdobných organizací). Zjištěné skutečnosti ilustrujeme údaji z přímých výpovědí jednotlivých vedoucích školských pracovníků z Německa a Rakouska, ${ }^{7}$ se kterými jsme na jaře a na podzim roku 2017 realizovali hloubkové rozhovory během zahraničních pobytů a návštěv v zahraničních školách (přehled respondentů uvádí tabulka 1). Výběr odborníků pro rozhovor nebyl náhodný, jednalo se o zkontaktování na základě osobního doporučení či získaný kontakt během návštěvy určité školy ( $v$ podstatě tedy metodou sněhové koule, jak uvádí například Hendl, 2005). Kromě ředitelů škol byly rozhovory vedeny i s oborovou koordinátorkou v Německu a ředitelem školského spolku v Rakousku. Tito dva odborníci byli vybráni záměrně, protože s ohledem na centrální rízení školských systémů je oborová koordinátorka zodpovědná za výběr a hodnocení učitelů ve školách $v$ jejím regionu (Sasko) a předseda vídeňského školského spolku se podílí spolu se školským inspektorem na výběru pedagogických pracovníků a na alokaci zdrojů. Rozhovory byly vedeny individuálně a byly bud' nahrány na diktafon, nebo byly bezprostředně po rozhovoru zapsány významné skutečnosti, které souvisely s diskutovaným tématem. V rozhovorech jsme se dotazovali na výše zmíněné tematické oblasti. Z hlediska práce s informacemi jsme postupovali od nejširšího úhlu

7 Realizovali jsme sedm rozhovorů s vedoucími pracovníky Německa ze spolkových zemí Sasko a Hamburk a Rakouska $v$ pěti školách. 
pohledu, tj. vycházeli jsme z úrovně státu, přes úroveň jednotlivých spolkových zemí až po konkrétní situaci v navštívených školách. Zjištěné skutečnosti z relevantních dokumentů doplněné o rozhovory tak poskytují plastičtější pohled na problematiku učitelských sborů v rozdílně řizených školských systémech a poskytují také prostor pro reflexi aktuálních otázek vzdělávání v České republice.

Tabulka 1 Rozhovory realizované v Německu a Rakousku

\begin{tabular}{llc}
\hline Zastávaná pozice & Země & Počet rozhovorů \\
\hline ředitelé (sekundární vzdělávání) & Německo & 2 \\
oborová pedagogická koordinátorka & Německo & 1 \\
ředitelka (primární vzdělávání) & Rakousko & 2 \\
ředitelka (sekundární vzdělávání) & Rakousko & 1 \\
předseda vzdělávacího spolku & Rakousko & 1 \\
\hline
\end{tabular}

Situace $v$ České republice byla mapována pomocí dat získaných z realizace dvou ohniskových skupin ředitelů základních škol realizovaných na podzim roku 2017 (přehledně tabulka 2). Dvě skupiny vždy po pěti osobách byly sestaveny z ředitelek a ředitelů škol různých velikostí i umístění, aby byla zajištěna co největší šíře možného pohledu právě vzhledem ke specifikům škol daných lokalitou i počtem pedagogických pracovníků. Kromě výzkumníka a respondentů byl př́tomen nezávislý, tzv. tichý, pozorovatel, jehož př́tomnost a pozdější ověření pomohlo zajistit vyšší míru objektivity. ${ }^{8}$ Některé $z$ autentických výpovědí jsou uvedeny přímo v následujícím textu.

Tabulka 2 Rozhovory realizované v České republice

\begin{tabular}{llcc}
\hline Zastávaná pozice & Kraj & Počet ohniskových skupin & Počet účastníků \\
\hline Ředitelé/ředitelky & Praha & 1 & 5 \\
základních škol & Jihomoravský & 1 & 5 \\
\hline
\end{tabular}

\section{Výsledky}

Dále prezentujeme hlavní výsledky studie $v$ tematických celcích odpovídajících položeným výzkumným otázkám. Nejprve se zaměřujeme na oblast vytváření učitelských sborů, dále na hodnocení a ukončování pracovního poměru, přičemž neustále reflektujeme a zohledňujeme roli ředitelů, jejich postoje a názory.

\subsection{Vytváření učitelských sborů}

Kromě zcela nově vzniklých škol se nejedná nikdy o náhle vytvořený a zcela nový učitelský sbor. Zpravidla jde o jeho doplňování, tj. pouze o několik procent nových

8 Při rozhovorech $v$ Německu a Rakousku tichý pozorovatel přítomen nebyl. 
54 učitelů $v$ daném učitelském kolektivu. Stabilita a kvalita učitelského sboru jsou nepochybně zásadními faktory, jež ovlivňují kvalitu poskytovaného vzdělání ve škole (např. Lukas, 2009; Rozkovcová \& Urbánek, 2017). V rámci fluktuace učitelů je možné hovořit o tzv. migraci učitelů (tj. odchodu na jinou školu), o odchodu mimo profesi (tzv. atrice) a o přirozeném odchodu do důchodu nebo na mateřskou/rodičovskou dovolenou (tamtéž). Právě migrace učitelů je u centrálně řizených systémů důležitým fenoménem při sestavování učitelských sborů a vzhledem $\mathrm{k}$ její centrální řízenosti umožňuje plánovat a umístovat učitele s ohledem na potřeby jednotlivých škol a zajistit tak, aby školám nechyběli pedagogičtí pracovníci (viz také výše zmíněná odpovědnost státu). V Rakousku vstupují učitelé do služebního vztahu se státem po ukončení školy. Během prvních pěti let mají smluvní vztah vždy na jeden rok a teprve po pěti letech získávají služební poměr na dobu neurčitou. Tento služební poměr není ale vázán $\mathrm{k}$ žádné konkrétní škole, ale ke státu. V Německu rovněž po zkušebních letech v tzv. referendariátu uzavírají učitelé smluvní služební vztah se státem (např. Lehrerausbildung..., 2017; Vertragsbedienstetengesetz, 2017; Vorbereitungsdienst..., 2017). V České republice neexistuje žádné zkušební či přechodné období pedagogických pracovníků po ukončení vysoké školy vyplývající ze školské legislativy a ani žádný smluvní vztah se státem, záleží na řediteli a učiteli, jak se smluvně dohodnou a jakou smlouvu uzavřou (samozřejmě při respektování př́slušných zákonů). Jedná se tedy o zcela odlišný proces, založený na jiném přistupu jak ze strany státu, tak i ředitelů a učitelů. V rámci tzv. individuálního národního projektu Kariéra byl v České republice sestaven návrh kariérového systému učitele, který počítal se vstupním adaptačním obdobím nastupujícího učitele. Dưležitost adaptační fáze zdůrazňovali i ředitelé $v$ rozhovorech: „Neumím si představit, že bych neměla přidělit nastupujícímu učiteli zkušeného uvádějícího učitele, bez toho by to snad ani nešlo. Jenže to jistě není běžná praxe ve školách. “ Tento návrh ovšem nebyl v roce 2017 Poslaneckou sněmovnou schválen a zavedení kariérového systému bylo odloženo prozatím na neurčito. Navíc $v$ poslední době sílí tlak na poměrně rychlé uzavírání pracovních smluv na dobu neurčitou, což ilustrují i výpovědi ředitelů českých škol:

„Pokud rychle nenabídnu smlouvu na dobu neurčitou, odejdou mi jinam. Nechce se věřit, že před pár lety jsem mohl smlouvu dvakrát prodloužit a teprve na základě kvalitního učitelského výkonu nabídnout neurčitou smlouvu. Fakt tady nechci zưstat sám.“

V Německu vypisují jednotlivé spolkové země výběrová rízení na uvolněná či nově vzniklá místa ve školách $v$ pravidelných, zpravidla půlročních cyklech, do kterých se uchazeči hlásí přes školské úřady, nedochází tedy k prrímému kontaktování škol a jejich ředitelů, jak je to běžné ve školách v České republice. Jednotlivé cykly jsou ve spolkových zemích stanovovány odlišně, nicméně tak, aby nebyly ohroženy výuka a stabilita učitelského sboru v průběhu školního roku. Ve spolkovém státě Hamburk se realizuje tzv. centrální přijímací proces (zentrales Einstellungsverfahren), kdy se uchazeči registrují u školského úřadu a následně jsou jejich podklady předávány školám na uvolněná pracovní místa s tím, že termíny nástupư jsou vždy k začátku 
školního roku a druhého pololetí. $V$ případě potřeby mohou školy kromě tohoto centrálního přijímání vypsat uvolněná místa $v$ jejich školách, na která se pak mohou uchazeči přes školský úřad hlásit př́mo, pak se jedná o tzv. školní přijímací proces (schulbezogenes Stellenausschreibungsverfahren). V př́padě, že je uchazeč přijat do určité školy, má zakázáno se účastnit dalších výběrových ř́zení, at’ již centrálně, nebo školou vypsaných (Die Einstellung von Lehrkräften..., 2017).

$Z$ rozhovoru s ředitelkami rakouských škol vyplynulo, že je jejich školní inspektor kličcovou osobou, která má rozsáhlé rozhodovací pravomoci, a fakticky se jedná o príimého nadřizeného ředitelů škol. ${ }^{9}$ Školní inspektor spravuje vždy jeden až dva školské obvody a $v$ nich umístěné školy. Pravidelně je navštěvuje a komunikuje s řediteli. Ředitelé jsou povinni se několikrát do roka společně scházet, radit se a diskutovat o zásadních otázkách týkajících se škol. Školní inspektor je také osobou, která přiděluje do škol učitele, řeši problematiku zastupování nemocných učitelů či situace při odchodu na mateřskou dovolenou nebo do penze. Rovněž dohližź na pravidelné hodnocení učitelů, především na hodnocení začínajících učitelů, a vykonává dozor nad jednotlivými školami (Bundes-Schulaufsichtsgesetz, 2017). Posílení autonomie přinese ředitelům možnost vybírat si své učitele, nicméně výběr zůstává nadále založen na centrální evidenci a služebních smlouvách učitelů se spolkovou zemí anebo státem. Učitelé obecních škol ${ }^{10}$ jsou smluvně vázáni s danou spolkovou zemí (tzv. Landeslehrer) a učitelé sekundárních stupňů škol jsou smluvně vázáni se státem (tzv. Bundeslehrer). Formální vztah školy, ředitele a učitele je tedy garantován spolkovou zemí a státem, jež uzavírají s učiteli služební smluvní vztah (Bundeslehrer-Lehrverpflichtungsgesetz, 2017; Landeslehrer-Dienstrechtsgesetz, 2017).

V České republice sestavuje učitelské sbory ředitel školy, vypisuje výběrová řízení, aktivně učitele vyhledává, spolupracuje s fakultami vzdělávajícími učitele, využívá osobních kontaktů, doporučení kolegů, organizuje pohovory a zodpovídá za celý proces (Trojan, 2017).

Co tedy přináší rozdílná míra autonomie při vytváření učitelských sborů a jaké klade požadavky na ředitele školy? V České republice se jedná o plně individuální proces, jak ze strany ředitele školy, tak i učitelů, kteří si také samostatně vyhledávají školy, kde by chtěli působit. Český ředitel je plně zodpovědný za to, jaký bude jeho učitelský sbor, a s touto optikou přistupuje i k výběru jednotlivých učitelů. Může rozhodovat na základě svých specifických kritérií a orientovat svou volbu podle potřeb své školy, což je možnost, kterou němečtí a rakouští ředitelé nemají. Učitelé se hlásí centrálně u př́slušných školských úřadů, které dále komunikují s řediteli škol ( $v$ Rakousku prostřednictvím př́slušného školského inspektora). Učitelé jsou vybíráni podle přesně a transparentně stanovených kritérií, kterými jsou napríklad kvalifikovanost, výsledky u státní závěrečné zkoušky a hodnocení na počátku vzdělávací dráhy ( $v$ Německu jde o zpravidla dvouleté období tzv. referendariátu a v Rakousku o prvních pět let pedagogické praxe). Jak uvedl $v$ rozhovoru ředitel gymnázia

9 Tento systém je staršími generacemi učitelů přirovnáván $\mathrm{k}$ situaci v Československu před rokem 1989.

10 Obecní školou se v Rakousku nazývají první čtyři roky primární školy. 
56 v Hamburku, není možné dát přednost kandidátovi s horším vysvědčením, i když má dle jeho názoru lepší pedagogické názory a vnímá ho jako přínosnějšího a vhodnějšího s ohledem na potřeby školy. „Pokud bych to takto chtěl rozhodnout, tak riskuji problém s úřadem, musel bych to složitě vysvětlovat, proč do školy nastupuje ten s horším vysvědčením. “ Na druhou stranu přináší stanovená jednoznačnost určité zjednodušení celého výběru a možnost garantovat všem stejný př́stup, který není závislý na osobnosti ředitele školy a jeho názoru na to, co je a není pro školu důležité. Jak již bylo řečeno výše, zpravidla se nejedná o vytvoření celého učitelského sboru najednou, ale spiše o jeho doplňování. Učitelé si tak v centrálně rízených systémech mohou být jisti, že ve všech školách platí stejná kritéria a všechny učitelské sbory byly budovány obdobným způsobem. Zároveň je ale mimořádně obtižné vytvářet učitelské sbory, které by spojovala obdobná vize, a ředitel školy musí pracovat se sborem, $v$ němž mohou být učitelé orientující se na různé pedagogické přístupy. Nicméně je třeba si také uvědomit, že možnost, kterou teoreticky český ředitel má, tj. sestavit si svůj sbor dle vize a zaměření školy, naráží na všeobecně známou realitu nedostatku učitelů. Jedná se převážně o učitele prvního stupně (např. Pišová \& Hanušová, 2016), ale i ve vyšších vzdělávacích stupních jsou aprobace, pro které je mimořádně obtižné nalézt kvalifikovaného učitele. „Černého Petra máme v rukou my na základkách. Pokud se ukáže dobrý učitel a přesáhne hranice školy, přetáhnou nám jej střední školy. To víte - gympl táhne, “ uvedla v diskusi česká ředitelka školy. Pak je tedy v podstatě celá možnost výběru v praxi zúžena na přijetí jakéhokoli kandidáta, který projeví o danou pozici zájem. Sehnat takového kandidáta musí v České republice ředitel školy, oporu ve školském úřadu či školním inspektorovi, jako jeho sousedé v Německu a Rakousku, nemá.

\subsection{Hodnocení a odměňování}

Při práci s „lidskými zdroji“ je nezbytné věnovat se hodnocení pracovního výkonu, motivaci a odměňování, což jsou v podstatě standardní a již mnohokrát popsané činnosti vedoucích pracovníků. $V$ prostředí školství mají svá specifika vycházející také $z$ míry autonomie, kterou $v$ této oblasti školy a jejich ředitelé disponují. Odměňování jako takové náleží zaměstnancům za odvedení jejich práce a vychází z pracovněprávních předpisů (kupř. Šikýř, 2014; Koubek, 2015). Nicméně, jak uvádí např́klad Šikýřr, Borovec a Trojanová (2016), je jeho smyslem „spravedlivě ocenit skutečný výkon zaměstnancư“ (s. 117), přičemž se jedná jak o peněžní, tak i nepeněžní formu. Finanční forma odměňování učitelů je zpravidla stanovována státem, a to jak $v$ Německu, $v$ Rakousku, tak i v České republice. Základní plat učitelů ve státních školách je stanoven př́slušnými tabulkami, které vycházejí z let pedagogické praxe a zastávané pozice $v$ rámci školy a školského systému (např. Besoldung Hamburgische..., 2017; Entgelttabelle für..., 2017; Gehalt für Lehrer..., 2017; Gehaltstabelle für..., 2017). $V$ tomto ohledu jsou podmínky (tím samozřejmě nemyslíme výši platů) shodné ve všech zmiňovaných státech. Výrazně rozdílné je ale přidělování tzv. nenárokových složek platu, tj. osobního ohodnocení a nadstandardních odměn. 
V centrálně ř́zených školských systémech zpravidla nerozhoduje o výši nenárokových složek platu ředitel školy, př́padně jsou jeho pravomoci v tomto směru výrazně omezené. Rakouští ředitelé nemohou učitelům poskytovat žádné finanční osobní ohodnocení a ani žádné nadstandardní odměny. $Z$ určitého úhlu pohledu se mǔže jednat o skutečně spravedlivější př́stup, který eliminuje možnost, že ředitel rozhoduje podle osobních preferencí. Tento systém zajišt'uje transparentní př́stup založený na přesně daných pravidlech (kupř. Št’astný, 2017). V Německu rovněž nemůže ředitel školy rozhodovat o osobním ohodnocení či ročních prémiích zaměstnanců, nicméně $v$ př́padě státem vypsané odměny (např. v navštíveném Sasku) je povinen nominovat určitý počet učitelů, kteří tento roční bonus získají. Nejedná se ale o pouhé rozhodnutí ředitele, jeho nominace se opírá o doporučení širšího vedení a názor učitelské konference. Tento způsob se jeví řediteli jako nevhodný, právě s ohledem na velké riziko rozhodování na základě oblíbenosti mezi jednotlivými učiteli, jak vyplynulo z rozhovoru s ředitelem saského gymnázia. Vyjadřuje-li se učitelská konference (tj. $\checkmark$ podstatě učitelský sbor), je $\mathrm{z}$ jeho úhlu pohledu pravděpodobné, že zvolí právě kolegu či kolegyni, kteři jsou v kolektivu oblíbení, a nebudou se rozhodovat podle př́nosu práce pro školu. „Toto prostě nemohou rozhodovat učitelé, ti nevidí všechno, to by mělo být na vedení školy, kdo dostane odměnu, bohužel to ale musíme dělat takto, “ uvedl dotazovaný ředitel.

V Rakousku není možné žádné odměňování za nadstandardní výkon, neexistují žádné roční odměny, bonusy či osobní ohodnocení. Učitelé jsou odměňováni všichni stejně, ředitel školy nemůže ovlivnit výši jejich platu a ani to není oblast, za kterou je zodpovědný. Ředitel školy připravuje výkazy o měsiční práci a př́padné pracovní neschopnosti, jež dále předává př́śsušnému školskému úřadu, který je zpracuje. Učitelé jsou vypláceni v podstatě s dvouměsíčním zpožděním, jak uvedla ředitelka navštívené školy. Školský úřad má totiž dva měsíce na zpracování mzdových podkladů. Všechny navštívené ředitelky zmínily, že nemohou nic dělat $s$ tím, když někdo pracuje lépe a více a jiný vykonává jenom to nejnutnější. Všechny rovněž shodně uvedly, že mohou maximálně poděkovat a potřást rukou. Jednou za rok mohou nominovat nejlepší kolegy na státní ocenění, které ale není spojeno s žádnou finanční odměnou, jak je tomu např́klad ve výše zmíněné nominaci v Sasku. Rakouští ocenění učitelé dostanou státní dekret na slavnostní ceremonii. Finanční motivace zaměstnanců tedy v podstatě není realizovatelná $v$ centrálně rízených školských systémech. Kromě motivace chválou musí ředitelé spoléhat na vnitřní motivaci učitelů, na jejich vlastní angažovanost pro učitelské povolání a ochotu k nadstandardním činnostem. Rakouské ředitelky také shodně uvedly, že na jednu stranu by uvítaly, kdyby mohly angažované pracovníky ocenit, na druhou stranu jsou ale rády, že nemusí otázku platů a financí řešit: „Kdybych ještě toto měla řešit, tak už nevím,“ uvedla konkrétně jedna z dotazovaných ředitelek. $V$ rozhovorech uváděly, že si nedovedou představit, že by se měly otázce finančního ohodnocení věnovat, měly pocit, že by to mohlo narušit vztahy ve sboru, kdyby mohly jednotlivé učitele oceňovat, a také by je to stálo mnoho času, ve kterém by musely připravovat podklady pro osobní ohodnocení, aby byla spravedlivě distribuována. Saský ředitel uvedl, že mu nevyhovuje, pokud 
58 má někoho výjimečně ocenit, že by bylo lepší, pokud by bud' dostal celou částku a mohl ji rozdělit dle vlastního uvážení, anebo by žádné ocenění nebylo. Nominace jednotlivců není (dle jeho názoru) dobrá pro klima sboru.

Kde je vưle, tam je cesta... Osobní rozhovory s řediteli škol ukázaly některé možnosti a cesty, které ředitelé centrálně řízených systémů mohou využívat, a oceňovat tak nadstandardní práci. Nejedná se o standardní postupy, ale s ohledem na popsanou metodologii článku, kdy postupujeme od nejobecnějšího popisu dané situace ke konkretizaci v jednotlivých školách, je legitimní je zde uvést, protože ukazují na možné individualizované přístupy vycházející z osobnosti jednotlivých ředitelů, kteři hledají své vlastní cesty a přístupy v rámci „mantinelů“ centrálního řizení škol. Při nominování osob na roční bonus se ředitel saského gymnázia obával, že učitelská konference rozhodne na základě oblíbenosti některých kolegů, a nikoli na základě skutečně kvalitní pedagogické práce. Obával se také, že by rozhodování mezi učiteli mohlo vyvolat nepř́ijemnou atmosféru s ohledem na to, že někteří byli svými kolegy nominováni a ostatní ne. Tuto situaci vyřešil následujícím způsobem: navrhl čtyři učitele, kteří si dle jeho názoru nejvíce zaslouží získat roční bonus, jejich jména prodiskutoval se členy širšího vedení a zdůvodnil jejich volbu, širší vedení mu nominaci po společné diskusi odsouhlasilo. Následně oslovil předsedu učitelské konference, informoval ho o závěrech širšího vedení a následně navrhl, že $v$ případě, že učitelská konference nebude s těmito jmény souhlasit, je připraven k projednání celé situace, a to co nejdřive, konkrétně v pátek odpoledne. Navržení pátečního odpoledního termínu eliminovalo jakýkoli protest, jak uvedl ředitel saského gymnázia: „Věděl jsem, že když řeknu pátek a ukážu protokol z širšího vedení, že nebude žádný problém a nominaci mi odsouhlasí.“ V Hamburku také není možné odměňovat učitele podle jejich aktivního př́stupu k práci, nicméně lze za určité aktivity snižovat počet hodin přímé pedagogické činnosti. Jedná se tedy o jakýsi bonus ve formě sice stejného platu, ale za méně odučených hodin. Ředitel školy může posoudit, kolik času je nutné věnovat jednotlivým školním projektům a nadstandardním aktivitám a kolik času je „odečteno“ z pracovní doby a přímé vyučovací činnosti. Kolegy tedy oceňuje formálním přidělováním funkcí, které jim umožní snížení přímé vyučovací činnosti. Zároveň tak může získat i nárok na další úvazek učitele pro svou školu.

\subsection{Ukončování pracovního poměru}

Situace, kdy ředitel či vedení školy nejsou spokojeni s prací jednotlivého učitele, je vždy komplikovaná, at' už se jedná o jakkoli řízený školský systém. Česká ředitelka školy uvedla:

„Zákoník práce mi neumožňuje v oblasti propouštění prakticky nic. Pokud se nejedná o trestný čin, nemám šanci - soud dá vždy za pravdu zaměstnanci. Pokud mám učiteli dokázat hrubé porušení pracovní kázně, musím ze sebe udělat trubku, např. čekat na pozdní příchod. Proč nemůže mít zaměstnavatel a zaměstnanec stejné podmínky, abych mohla třeba několik měsíců předem nabídnout ukončení poměru?“ 
V této situaci se odvolává na zákoník práce, ve kterém mají učitelé v České republice stejné postavení jako všichni ostatní zaměstnanci, tj. jejich pozice a pozice jiných vedoucích pracovníků je v tomto případě stejná, a porušení pracovní kázně, at' již se jedná o hrubé, či tzv. soustavné méně závažné porušování povinnosti vyplývající z právních předpisů (§ 52 odst. g zákoníku práce). Česká republika s možností propouštět učitele za stejných podmínek jako jiné zaměstnance (tj. v souladu s příslušným ustanovením zákoníku práce) je v podstatě jednou z velmi mála zemí, kde je něco takového možné. ${ }^{11}$ Propouštění je totiž právě oblastí, ve které mají školy a jejich ředitelé nejmenší pravomoci (School autonomy..., 2011).

Má-li německý či rakouský učitel služební poměr na dobu neurčitou, nebo je dokonce jmenován státním úředníkem, je jeho propuštění v podstatě nemožné. „Jediná možnost, jak se ve škole někoho zbavit, je, že přejde sám na jinou školu,“ uvedl hamburský ředitel a dodal: „Jednou učitel, navždy učitel.“ Nulová autonomie $v$ této oblasti přináší učitelským sborům samožrejmě jistotu zaměstnání, kterou čeští učitelé nemají. Nicméně $k$ dosažení této jistoty vede $v$ Německu i Rakousku několikaletá cesta (např. Lehrerausbildung..., 2017; Vertragsbedienstetengesetz, 2017; Vorbereitungsdienst..., 2017). Němečtí učitelé po absolvování vysoké školy nejsou hned samostatnými učiteli jako v České republice, ale musí absolvovat zpravidla rok a půl či dva roky tzv. referendariát (což je v podstatě výuka pod vedením zkušeného učitele), na jehož konci skládají teoretické i praktické zkoušky, které mají ověřit jejich pedagogické kompetence. Úspěšnost u těchto závěrečných zkoušek je rozdílná, jak dle jednotlivých spolkových zemí, tak dle vyučovaných předmětů, obvykle se pohybuje v rozpětí 90-95 \% (např. Vieth-Entus, 2010). Rakouští učitelé mají prvních pět let své pedagogické praxe smlouvy pouze na jeden rok, na jehož konci jsou vždy komplexně hodnoceni a je možné s nimi smlouvu dále neprodloužit v případě nevyhovujících výkonů. Pokud tato zkušební léta učitelé úspěšně absolvují, stávají se v podstatě doživotními učiteli a zbavit je této funkce je mimořádně obtížné.

Rakouská ředitelka obecní školy uvedla, že již několikrát během své kariéry napsala negativní hodnocení začínajícím učitelům, ale nepředpokládá, že byli zbaveni možnosti pracovat jako učitelé, spiše byli přeřazeni do jiných škol. Dle jejího názoru by ale úplné propuštění nebylo správné, protože „není přece možné rozhodnout na základě názoru jedné ředitelky, když nevyhovuje mně, mưže být úspěšný jinde. A je na to celkem pět let..." Všichni dotazovaní vedoucí pracovníci uvedli, že v případě, že učitel opouští jejich školu na základě nějakého problému, jedná se o jeho přeřazení jinam, údajně jsou učitelé, kteří takto „putují“ mezi školami jako „černý Petr“. „To už je takový malý alarm, když člověk vidí v životopise každý rok jinou školu,“ uvedla německá oborová koordinátorka.

Ředitelé německých škol (ze Saska a Hamburku) zcela shodně popsali mimořádně náročný proces, během kterého chtěli propustit zcela nekompetentního učitele. Zajímavé je, že u obou probíhal tento proces v podstatě stejně a trval také stejnou

11 Samozřejmě ani v ČR se nejedná o libovůli ředitelů a je nutné respektovat příslušná ustanovení zákoníku práce. Jeho podoba je ovšem poměrně rigidní, je to často pojmenováváno právě řediteli škol. 
60 dobu, tj. zhruba dva školní roky. $V$ obou případech se jednalo o učitele, na kterého byla řada stížností ze strany rodičů i žáků a jehož výuka nebyla kvalitní. Oba ředitelé se obrátili na školský úřad s žádostí o pomoc a čekal je dlouhodobý vyčerpávající proces sledování učitele a dokládání jeho nekompetence. Oba shodně uvádějí, že naplnili dva plné šanony poznámek a dokladů o tom, že je tento učitel skutečně nekvalitním pedagogickým pracovníkem. V Sasku nakonec ředitel pochopil, že jedinou cestou, jak toto vyřešit, je přistihnout ho při porušení služebních povinností, což je například opakovaný pozdní příchod do výuky. Tento pozdní příchod musí být písemně dosvědčen ještě alespoň jedním dalším učitelem. Ostatní učitelé se ale obávali něco takového udělat, přestože i širší vedení souhlasilo s ředitelem školy, že tento pracovník by ve škole být neměl. „Nakonec ale jedna učitelka přišla a řekla, že toto nikdy ve svém životě neudělala a už to nikdy neudělá, ale že byla právě svědkem, kdy přišel o pět minut později, a že mi to podepiše, pak byl konečně přeřazen na jinou školu, “ uvedl ředitel školy. V Hamburku učitelská konference odmítla potvrdit nekvalitu učitele se zdůvodněním, že jejím smyslem je v souladu se zákonem (§ 57 hamburského školského zákona) učitele zastupovat, a nikoli hodnotit. Celý př́pad vyústil v komplikované jednání na př́slušném školském úřadě, které nakonec rozhodlo o přeřazení učitele na jinou školu. Ředitel hamburské školy uvedl:

„Nedali mi za pravdu, řekli, že možná je v právu učitel, ale že to evidentně na škole nefunguje, a to se mưže stát. A pokud to takhle nefunguje, jeden musí jít jinam, ředitele nepřeřadí. Můj názor má tedy přednost a přeřazen musí být učitel, protože to je nakonec pro dobro všech.“

Přeřazení, tedy již výše jmenovaná migrace učitelů, může tedy být v Německu i Rakousku určitou formou stigmatu, u kterého není zcela jasné, z jakého důvodu ke změně školy u učitele došlo. Je pravda, že ředitelé škol shodně uváděli, že učitelský sbor je převážně stabilní, že většinou přišli již ke sboru, který mají dosud, a žádné velké změny se za jejich působení neudály (tj. ani přijímání nových učitelů). Také z diskuse $s$ jednotlivými učiteli v navštívených školách vyplynulo, že nemají zájem školu měnit, protože $v$ této mají již vybudovanou pozici a nevidí ke změně žádný důvod. Je tedy možné, že u učitele přecházejícího z jiné školy (bez udaného logického důvodu, kterým je například stěhování za rodinou) je ze strany ostatních nutná určitá obezřetnost, protože je vždy možné, že jde o tzv. černého Petra, putujícího ze školy do školy, jak zmínila německá oborová koordinátorka.

\section{Diskuse}

V závěrečné diskusi bychom se rádi podívali na otázky př́nosu autonomie škol pro učitelské sbory optikou aktuálně řešených témat v oblasti vzdělávání. Hledisko spravedlivosti ve vzdělávání je tématem řady aktuálních výzkumných projektů a poukazuje mimo jiné na aspekt rovnosti podmínek ve vzdělávání. Rovnost podmínek znamená i srovnatelnou kvalitu učitelských sborů ve všech školách (např. Greger, 
2006). Všichni žáci mají nárok na stejné podmínky vzdělávání, které jsou garantované státem, tj. všechny školy musí poskytovat stejnou nabídku, co se týče kvalifikace zaměstnanců a vzdělávací nabídky. Právě o tento princip se opírá centrálně řízené sestavování učitelských sborů a dohled nad jejich fungováním. Jsou-li sbory sestavovány na základě jednotných kritérií, v předem známých intervalech a za stejných podmínek pro všechny školy, je možné zajistit spravedlivou „distribuci“ pedagogické síly pro všechny školy a tím spravedlivé podmínky pro žáky. Nicméně i v centrálně řízených systémech je bráno v potaz přání učitele a není „umíst’ován“ zcela libovolně. Ředitelé se rovněž účastní výběrového řízení a podílí se na finálním rozhodnutí. Jejich rozhodovací podíl spočívá především $v$ komunikaci s jim nadřízeným orgánem (tj. př́slušným školským úřadem $v$ Německu a odpovědným školním inspektorem v Rakousku). Záleží hodně na vzájemném vztahu, a tedy i ochotě se domluvit a vyjednat vhodného učitele pro svou školu, jak uváděli shodně ředitelé v rozhovorech. „Vždy se nějak s inspektorem domluvím. Řeknu mu, koho bych si představovala, a on mi ho přidělí, “ uvedla ředitelka rakouské obecní školy. Oborová koordinátorka popsala i další způsob vyjednávání při přidělování učitelů: „Když člověk o někoho stojí, někdy pomůže, když si vezme i nějakého toho černého Petra... Podle motta potřebuješ dobrého němčináře, tak musiš snést $i$ tohoto chemikáře.“

Vrátíme-li se tedy k položené výzkumné otázce: Jakým způsobem se vytvářejí učitelské sbory ve vybraných státech a jakým způsobem mohou ředitelé škol tento proces ovlivňovat? - docházíme k závěru, že je svým způsobem iluzorní věřit tomu, že centrální rízení zajistí spravedlivou distribuci učitelů mezi jednotlivé školy. Vždy budou různí a různě schopní ředitelé škol, kteří budou hledat cesty, jak získat kvalitní učitele pro své školy a jak ovlivnit podobu a složení svého pedagogického sboru, at' už se jedná o centrální, či decentralizovaný školský systém.

Zmíněná spravedlivá distribuce pedagogické síly ve školách je v České republice také poměrně komplikovaná. Otevřeně je potřeba pojmenovat, že v České republice dochází k pokračující selekci škol i žáků a k pomyslnému otevírání nůžek mezi jednotlivými sociálními skupinami. Běžné veřejné základní školy a zejména jejich ředitelé se dostávají do obrovského tlaku, s nímž si nemusí v blízké budoucnosti již sami vědět rady. Učitelé si vybírají pro svou působnost „jednodušši“ nebo „lepši““ školy a běžné základní školy a jejich ředitelé se potýkají se silným nedostatkem učitelů (a možnost autonomního výběru a vlivu ředitele školy na podobu učitelského sboru tak zůstává spíše iluzí). „Je to smutné, ale já už musím vzít prakticky kohokoli. Podle školského zákona již není důležitá aprobace, ale co mi řekne inspektor, když dám hodiny matematiky češtinářii?“ uvedla ředitelka městské základní školy a dodala: „Ano, učitelka odešla na vedlejší školu s tím, že tam paní ředitelka bude chtít mnohem méně. U nás prý měla každou chvíli dělat něco navíc. Jak mám potom tlačit učitele ke kvalitní práci?“ Další ředitel uvedl: „...to, co je podle mne běžná pracovní náplň, začínají někteří učitele považovat za zátěž. Třeba dozory, komunikaci s rodiči, setkávání s jinými učiteli.“

Mezi aktuálně diskutovaná témata jistě patří otázka posilování autonomie škol $v$ centrálně řízených školských systémech a zvyšování jejich pravomocí, s čímž sou- 
62 visí i zvyšování pravomocí ředitelů škol. Výzkumy dokládají vliv autonomie na vzdělávací výsledky jednotlivých žáků a jejich úspěšnost v mezinárodních testech, přičemž dávají do souvislosti vztah autonomie a odpovědnosti škol za výsledky vzdělávání (např. Dvořák et al., 2014). V Rakousku je patrná silná snaha a diskuse o možnostech posílení školní autonomie, kterou reprezentuje i tzv. balíček pro školní autonomii (Schulautonomiepaket), který vydala vláda v roce 2017 (Die Regierung präsentiert..., 2017). Tento balíček se zaměřuje také na oblast pedagogických sborů a cílí na posílení pravomocí ředitelů škol, kterým tímto způsobem chce umožnit vybírat si učitele a utvářet společně specifickou podobu řízené školy. Důležitá otázka též je, zda jsou ředitelé centrálně řizených školských systémů připraveni na plánované změny v souvislosti s posilováním své autonomie. Podíváme-li se např́klad na oblast vedení lidí $s$ ohledem na potřebné kompetence ředitele $v$ centrálně řizeném školství a při plné autonomii, jedná se o odlišné kompetence, jiné specifické znalosti a dovednosti, pro které je potřeba také jiná př́prava školských manažerů (např. Trojan, 2016). Vzdělávání školských manažerů, jejich podpora a př́prava na funkci by se měly orientovat dle toho, jaké kompetence od nich jejich role vyžaduje, což vychází především ze způsobu, jakým jsou školské systémy řízeny, jaké pravomoci v nich ředitelé mají a jaké konkrétní činnosti jsou od nich vyžadovány (kupř. Trojan, 2011). Jiné kompetence bude potřebovat ředitel, který sám sestavuje svůj učitelský sbor, následně ho hodnotí, rozvíjí a též odměňuje dle kvality výkonu jednotlivých osob (Lhotková, Trojan, \& Kitzberger, 2012). Jiné kompetence potřebuje ředitel, který spravuje učitelský sbor vytvořený centrálně, bez možnosti finančně odměnit nadstandardní výkon a rovněž bez možnosti propustit nekvalitního zaměstnance. Smysluplně stanovit národní kompetenční model pro řídící pedagogické pracovníky a jemu odpovídající vzdělávání, přípravu a profesní podporu by mělo být důležitým úkolem vzdělávací politiky, která by pak následně ovlivnila i fungování jednotlivých škol a jejich učitelských sborů.

Posilování autonomie škol zcela jistě ovlivňuje jejich fungování ve všech rovinách, nicméně se nejedná o izolované téma. Jak jsme již zmínili, jednou stranou pomyslné mince je míra autonomie, tou druhou faktické možnosti, které v daném státě existují. Pojí se s tím otázka, zda existuje dostatek učitelů, ze kterých je možné zodpovědně sestavit učitelský sbor, jestli existují potřebná stabilita a jistota, že takto sestavený sbor bude dlouhodobý, a také to, disponuje-li ředitel školy potřebnými kompetencemi pracovat, at' již s přiděleným, či samostatně sestaveným učitelským sborem.

\section{Závěr}

V naší studii jsme se věnovali otázce: Co přináší autonomie učitelským sborům a jaké klade požadavky na ředitele školy? - přičemž jsme se zaměřili na vytváření učitelských sborů, jejich odměňování a také na téma propouštění učitelů v německém a rakouském prostředí, které jsme komparovali se situací v České republice. $V$ dis- 
kusní části jsme tuto problematiku zasadili do aktuálně řešených témat $v$ oblasti školství a vzdělávání, a to především do tématu spravedlivosti ve vzdělávání a posilování školské autonomie. Zásadním zjištěním studie je, že rozdílný rozsah pravomocí vede k odlišným strategiím $v$ práci s lidskými zdroji ve školách, a to ve všech zkoumaných oblastech. Ředitelé zkoumaných centrálně rízených systémů musí hledat cesty, jak se „domluvit“ s nadřizeným orgánem, a zajistit tak kvalitní učitele pro své školy. V př́padě, že nejsou spokojeni s prací učitelů, hledají cesty k jejich „dobrovolnému“ přeřazení. Čeští ředitelé disponující rozsáhlými pravomocemi se při práci se svými sbory potýkají s jinými problémy - mj. naprostým nedostatkem učitelů či jejich koncentrací v tzv. lepších školách - a hledají jiné cesty, jak si získat a udržet kvalitní sbor, kupř. nestandardně rychlým nabízením smluv na dobu neurčitou.

Určitým faktorem, který autonomie učitelským sborům přináší, je svoboda, a to jak na straně ředitelů, kteří mohou ovlivňovat sestavení svého učitelského sboru, tak i na straně učitelů, kteři mohou volit školy, ve kterých budou působit. Tato svoboda, která může na první pohled působit jako veskrze pozitivní př́nos autonomních škol, mǔže mít ale ve svém důsledku i negativní dopad na vlastní fungování škol (a na žáky v nich). Umožňuje totiž koncentraci učitelů v „lepších“ školách či u „lepších“ ředitelů a může mít dopad na výsledky vzdělávání ve školách, jejichž ředitelům se nedaři sehnat kvalifikované pedagogické pracovníky. Vzhledem $\mathrm{k}$ tomu, že $v$ Německu a Rakousku je postupně školská autonomie posilována, považujeme za zásadní nadále $v$ tomto tématu výzkumně pokračovat, sledovat změny $v$ př́stupu ředitelů škol $v$ měnících se podmínkách a navázat na tuto studii $\checkmark$ následujících letech.

\section{Literatura}

Abari-Ibolya, E., \& Baráth, T. (2010). Improving school leadership in Central Europe. Budapest: Tempus Public Foundation.

Barber, M., \& Mourshed, M. (2007). How the world's best-performing schools come out on top. Dostupné z http://www.smhc-cpre.org/wp-content/uploads/2008/07/how-the-worlds -best-performing-school-systems-come-out-on-top-sept-072.pdf

Behbahani, A. (2011) Educational leaders and role of education on the efficiency of schools principals. Procedia - Social and Behavioral Sciences, 15, 9-11. DOI: 10.1016/j. sbspro.2011.03.040

Besoldung Hamburgische Beamtinnen und Beamten: Besoldungstabellen 2017/2018. (2017). Hamburg: GEW Landesverband Hamburg. Dostupné z https://www.gew-hamburg.de/sites /default/files/download/besoldungstabelle_hamburg_2017_18.pdf

Bildungsreformgesetz 2017. (2017). Bundesgesetzblatt, 138/2017.

Bundeslehrer-Lehrverpflichtungsgesetz - BLVG (2017). Bundesgesetzblatt, 138/2017. Dostupné také $\mathrm{z}$ https: / / www.ris.bka.gv.at/GeltendeFassung.wxe?Abfrage=Bundesnormen\&Gesetzesnummer $=10008205$

Die Einstellung von Lehrkräften in den Schuldienst der Freien und Hansestadt Hamburg im Kurzüberblick. (2017). Dostupné z http://www.hamburg.de/bsb/bewerbungen-online/64692 /hinweise-einstellungsverfahren/

Die Regierung präsentiert Autonomiepaket als „Herzstück der Bildungsreform“. (2017). Wien: Bundesministerium für Bildung. Dostupné z https://www.bmb.gv.at/ministerium /vp/2017/20170317.html 
64 Dvořák, D., Urbánek, P., \& Starý, K. (2014). High autonomy and low accountability: Case study of five Czech schools. Pedagogická orientace, 24(6), 919-940. DOI: 10.5817/PedOr2014-6-919

Entgelttabelle für die Entgeltgruppen 1 bis 15: gültig vom 1. Januar 2017 bis 31. Dezember 2017. (2017). Sachsen: Landesamt für Steuern und Finanzen. Dostupné z http://www.lsf. sachsen.de/download/Tarif/Entgelttabelle_TV-L_01.01.17-31.12.17.pdf

Eurydice (2007). Autonomie škol v Evropě. Politická a realizační opatření. Brusel: autor. Dostupné z http://eacea.ec.europa.eu/education/eurydice/documents/thematic_reports/090CS.pdf

Gehalt für Lehrer: Lehrergehalt für Beamte und Tarifangestellte. (2017). GEW. Dostupné z http://www.oeffentlichen-dienst.de/news/69-gehalt/300-grundschullehrer-gehalt-lehrergehalt.html

Gehaltstabelle für LehrerInnen 2018. (2017). Österreichische Lehrer/Innen Initiative. Dostupné z https://www.oeliug.at/recht/gehalt/gehaltstabelle/

Greger, D. (2006). Spravedlivost českého školského systému v mezinárodním srovnání. Orbis Scholae, 0(1), 46-59.

Hamburgisches Schulgesetz: HmbSG (2016). Hamburg: Behörde für Schule und Berufsbildung. Hendl, J. (2005). Kvalitativní výzkum: základní metody a aplikace. Praha: Portál.

Huber, S. G. Ed. (2009). School leadership - international perspectives. Dordrecht: Springer. Janík, T., Knecht, P., Kubiatko, M., Pavlas, T., Slavík, J., Solnička, D., \& Vlček, P. (2011). Kvalita školy a kurikula od expertního šetření ke standardu kvality: Výzkumná zpráva. Praha: Národní ústav pro vzdělávání.

Koubek, J. (2015). Řizení lidských zdrojů: základy moderní personalistiky. Praha: Management Press.

Kuuskorpi, M. \& Cabellos González, N. (2011). The future of the physical learning environment: school facilities that support the user. Paris: OECD. DOI: $10.1787 / 5 \mathrm{~kg} 0 \mathrm{kzz} d 9 \mathrm{f} 2$-en

Landeslehrer-Dienstrechtsgesetz - LDG 1984. (2017). Bundesgesetzblatt, 138/2017. Dostupné také z https: / / www.ris.bka.gv.at/GeltendeFassung.wxe?Abfrage=Bundesnormen\&Gesetzesnummer $=10008549$

Lazarová, B., Pol, M., \& Sedláček, M. (2015). Mezinárodní šetření TALIS 2013. Praha: Česká školní inspekce.

Lehrerausbildung im Freistaat Sachsen. (2017). Dresden: Staatsministerium für Kultus. Dostupné z https: / / www.lehrerbildung.sachsen.de/132.htm

Leithwood, K. (2005). Educational leadership: A review of the research. Philadelphia: The Laboratory for Student Success. Temple University.

Leithwood, K., Sun, J., \& Pollock, K. (2017). How school leaders contribute to student success: the four paths framework. New York, NY: Springer.

Lhotková, I., Trojan, V., \& Kitzberger, J. (2012). Kompetence rídících pracovníků ve školství. Praha: Wolters Kluwer ČR.

Lukas, J. (2009). Vztahy mezi učiteli a řediteli na základních školách - přehled relevantních výzkumů. Studia paedagogica, 14(1), 127-145.

Moree, D. (2013). Učitelé na vlnách transformace: kultura školy před rokem 1989 a po něm. Praha: Karolinum.

MŠMT. (2009). Zpráva o vývoji českého školství od listopadu 1989 (v oblasti regionálního školství). Dostupné z http: / / www.msmt.cz/vzdelavani/skolstvi-v-cr/strategicke-a-koncepcni-dokumenty-cerven-2009

Mulford, B. (2008). The leadership challenge: improving learning in schools. Camberwell: ACER Press.

Obdržálek, Z., \& Polák, J. (2008). Príprava školských manažérov ako klúčový predpoklad efektívnosti školy. Nitra: Univerzita Konštantína Filozofa.

Píšová, M., \& Hanušová, S. (2016). Začínající učitelé a drop-out. Pedagogika, 66(4), 386-407. DOI: $10.14712 / 23362189.2016 .353$

Robinson, V., Hohepa, M., \& Lloyd, C. (2009). School leadership and student outcomes: identifying what works and why: best evidence synthesis iteration (BES). Wellington: Ministry of Education. 
Rozkovcová, A., \& Urbánek, P. (2017). Fluktuace učitelů: vybrané zahraniční teorie a výzkumné prístupy. Studia paedagogica, 22(3), 25-40.

School autonomy and accoutability: Are they related to student performace? (2011, October). PISA in Focus. Dostupné z www.oecd.org/dataoecd/17/43/48910490.pdf.

Sofatutor. (2016, September 08). Verbeamtung: Wo werden Lehrer verbeamtet? [Online]. Sofatutor-Magazin Lehrer. Dostupné z http://magazin.sofatutor.com/lehrer/2016/09/08/verbeamtung-wo-werden-lehrer-verbeamtet/

Šikýř, M. (2014). Nejlepši praxe v řízení lidských zdrojů. Praha: Grada.

Šikýř, M., Borovec, D., \& Trojanová, I. (2016). Personalistika v řízení školy. Praha: Wolters Kluwer.

Št’astný, V. (2017). Aktuální pohledy na vzdělávání v Rakousku: zpráva ze studijního pobytu ve Vídni. Pedagogická orientace, 27(3), 504-512.

Tomková, A. (2012). Rámec profesních kvalit učitele: hodnoticí a sebehodnotící arch. Praha: Národní ústav pro vzdělávání.

Trojan, V. (2011). Vzdělávání řídicích pracovníků v českém školství: programy a hodnocení jejich obsahu účastníky. Orbis scholae, 5(3), 107-122.

Trojan, V. (2014). Pedagogický proces a jeho rízení. Praha: Wolters Kluwer.

Trojan, V. (2016). Neřešené otázky profesní přípravy ředitelů škol a jejich dalšího rozvoje. Andragogická revue, 8(1), 62-70.

Trojan, V. (2017). Řizení pedagogického procesu v současné škole. Praha: PedF UK.

Vertragsbedienstetengesetz 1948 - VBG. (2017). Bundesgesetzblatt, 138/2017. Dostupné z https: / / www.ris.bka.gv.at/GeltendeFassung. wxe?Abfrage=Bundesnormen\&Gesetzesnummer $=10008115$

Vieth-Entus, S. (2010, 08. 06.). Immer mehr Junglehrer fallen durch: GEW kritisiert Belastung der Referendare. Der Tagesspiegel. Dostupné z https://www.tagesspiegel.de/berlin/ immer-mehr-junglehrer-fallen-durch/1854374.html

Vorbereitungsdienst (Referendariat): Informationen für die Bewerbung. (2017). Dostupné z http://www.hamburg. de/bsb/vorbereitungsdienst/64638/bewerbungen-vorbereitungsdienst/

Zákoník práce. (2006). Zákon č. 262/2006 Sb.

Mgr. Zuzana Svobodová, Ph.D., katedra andragogiky a managementu vzdělávání Pedagogická fakulta, Univerzita Karlova Myslíkova 7, 11000 Praha zuzana.svobodova@pedf.cuni.cz

PhDr. Václav Trojan, Ph.D., katedra andragogiky a managementu vzdělávání Pedagogická fakulta, Univerzita Karlova Myslíkova 7, 11000 Praha vaclav.trojan@pedf.cuni.cz 